\title{
Komunikasi Device-to-Device pada Jaringan Seluler 5G menggunakan mmWave
}

\author{
Rasheed Abdurrahman Mulyadi* dan Uke Kurniawan Usman \\ Fakultas Teknik Elektro, Universitas Telkom \\ * email: rasheedam17@gmail.com
}

\begin{abstract}
This article discusses about device-to-device communication on $5 G$ cellular networks using mmWave. Device-to-device communication will support $5 G$ cellular technology, because it can be a solution to overcome the limitations of cellular coverage and service capacity. D2D can be used in a variety of applications. The main problem in D2D is that interference between signals in one cell will be very vulnerable to occur, so that effective resource management is needed. In addition, the use of D2D will also increase the complexity of a cellular system, in terms of resource management, interference, and also the routing required. Several studies have been carried out to create D2D communication that can be implemented effectively on $5 G$. One of them is research to perfect the load balancing scheme which is one of the functions obtained from D2D communication. Load balancing is the distribution of cellular traffic loads, using D2D the traffic load is channeled to communication between devices and reduces the burden on the main network.
\end{abstract}

Keywords-Device-to-device, D2D, Load Balancing, 5G

\section{Pengantar}

Jaringan seluler generasi kelima $(5 \mathrm{G})$ sedang dikembangkan untuk meningkatkan kecepatan trafik komunikasi dan kebutuhan komunikasi yang sudah meningkat secara drastis, terutama diantara perangkat seluler. Dengan munculnya berbagai aplikasi multimedia yang membutuhkan kecepatan transfer data yang tinggi, keterbatasan bitrate semakin terasa dan semakin diperlukan adanya perbaikan. Generasi seluler yang sebelumnya, generasi keempat (4G) sudah secara umum dipakai, dari standar yang telah dikeluarkan perbandingan kinerja antara 4G dan 5G dapat dilihat pada Tabel 1.

Tabel 1. Perbandingan Kinerja Teknologi Seluler 4G dan 5G [1-2]

\begin{tabular}{c|c|c}
\hline Kinerja & 4G LTE & 5G \\
\hline Bandwidth sistem & $20 \mathrm{MHz}$ & $0,1-20 \mathrm{GHz}$ \\
\hline Bitrate & $100 \mathrm{Mbps}$ & $20 \mathrm{Gbps}$ \\
\hline Spektrum frekuensi & $\begin{array}{c}800 \mathrm{MHz}, 1,8 \mathrm{MHz}, \\
2,6 \mathrm{MHz}\end{array}$ & $3,6 \mathrm{GHz},>24 \mathrm{GHz}$ \\
\hline
\end{tabular}

Kebutuhan data rate dan pertumbuhan pengguna yang terus meningkat, mengakibatkan tuntutan untuk kesediaan bandwidth semakin tinggi dan keterbatasan frekuensi pada pita yang tersedia saat ini semakin terasa. Sehingga jaringan teknologi $4 \mathrm{G}$ tidak lagi dapat mendukung secara penuh kebutuhan pengguna seluler. Dengan jaringan seluler 5G, diharapkan memiliki kapasitas jaringan yang jauh lebih tinggi dan memberikan kecepatan data multi-gigabit per detik untuk setiap pengguna untuk mendukung aplikasi multimedia dengan persyaratan kualitas layanan (QoS) yang ketat. 
Salah satu cara untuk mengatasi keterbatasan pita frekuensi untuk menyediakan komunikasi dengan bandwidth yang lebar adalah dengan menggunakan spektrum pada frekuensi tinggi (30-100 GHz) atau yang biasa disebut sebagai Milimeter-Wave (mmWave).

Bandwidth sistem yang besar diharapkan dapat diwujudkan dalam pita tersebut, dan memungkinkan peningkatan kecepatan data rate yang sangat tinggi dengan teknik yang relatif sederhana karena bandwidth sistem diperbesar. Sistem komunikasi 5G mmWave menawarkan koneksi data tinggi, latensi rendah dengan kecepatan gigabit untuk miliaran pengguna.

Penggunaan mmWave bukanlah tanpa tantangan, dengan menggunakan mmWave pengaruh penghalang atau obstacle akan semakin besar dan cakupan sel yang dihasilkan akan jauh lebih kecil dibandingkan pada frekuensi yang lebih kecil. Hal ini diakibatkan karena nilai penetration loss akan semakin besar, seiring dengan besarnya nilai frekuensi carrier yang digunakan [3],[4]. Penelitian lain juga telah dilakukan dalam bagaimana mmWave sangat terpengaruh oleh bahan medium dari obstacle, analisis dilakukan untuk femtocell pada skenario outdoor maupun indoor [5].

Dalam mengatasi peningkatan kepadatan trafik, dan mengatasi keterbatasan cakupan sel pada teknologi 5G, telah dikembangkan komunikasi device-to-device (D2D). Komunikasi D2D merupakan fitur yang memungkinkan user dapat berkomunikasi secara langsung tanpa melalui access point atau base station. Teknologi ini memungkinkan dua unit user equipment (UE) berkomunikasi satu dengan yang lain pada jarak tertentu, dan salah satu fitur lain yang sedang dikembangkan adalah dimana satu user yang didalam cakupan sel jaringan, dapat membagikan aksesnya dan memperluas cakupan sel dari jaringan. Selain pada perangkat user D2D juga akan berguna dalam perkembangan Internet of Things (IoT), dimana alat-alat akan saling terhubung dan dapat berkomunikasi. Salah satu contohnya adalah pada sensor-sensor yang saling terhubung, bertukar data dan dapat membuat keputusan secara otomatis. Pemanfaatan lain dari komunikasi D2D adalah dapat membantu mengembalikan kondisi layanan pada daerah paska bencana. Dapat dilihat pada Gambar 1, bagaimana sistem komunikasi D2D dapat membantu membangun kembali jaringan seluler paska bencana [6].

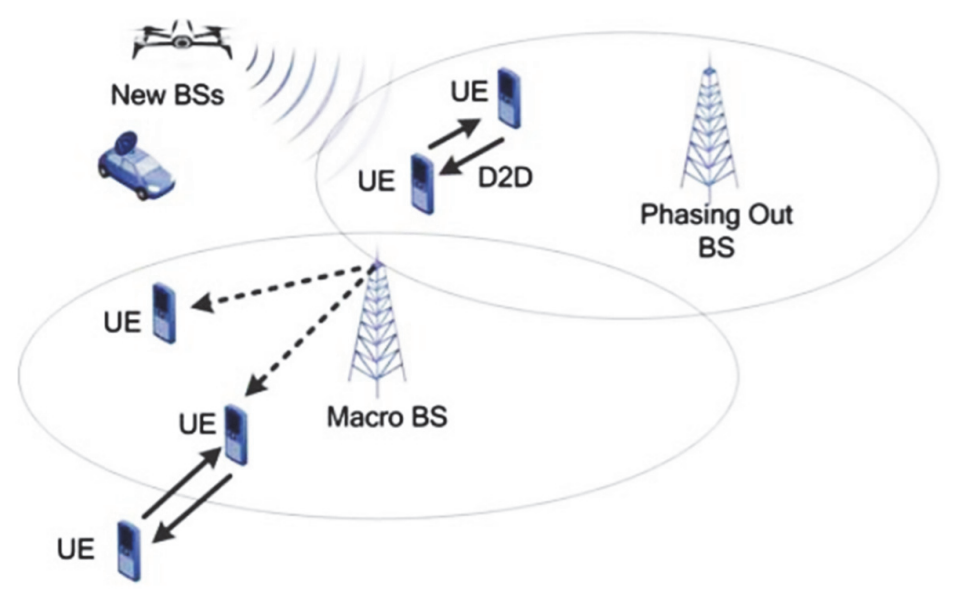

Gambar 1. Ilustrasi penggunaan D2D untuk aplikasi penanggulangan jaringan pada daerah paska bencana

Dapat dilihat, bagaimana D2D dapat meneruskan sinyal dan dapat menaikan coverage jaringan selular pada daerah paska bencana. Sinyal dari base station baru atau base station sementara pada daerah paska bencana akan diteruskan oleh user yang berfungsi sebagai relay pagi pengguna lain. 
Salah satu kegunaan utama komunikasi D2D dalam 5G adalah sebagai load balancing, dimana beban trafik dalam sel yang sangat padat dapat diurai dengan memanfaatkan D2D. Namun, dalam wilayah yang tercakup dalam layanan base station, dimana terdapat dua komunikasi secara bersamaan dapat mengakibatkan gangguan atau interferensi satu dengan yang lain. Hal tersebut disebabkan oleh penggunaan frekuensi carrier yang berdekatan dan daya pancar yang diberikan oleh masing-masing UE. Pada paper ini, akan dibahas beberapa permasalahan dan keuntungan dalam implementasi D2D pada jaringan seluler 5G mmWave.

\section{Konsep Komunikasi Device-to-Device}

Komunikasi device to device (D2D) merupakan teknologi yang dikembangkan untuk menyokong komunikasi pada perangkat telepon seluler pada generasi selanjutnya, 5G. Teknologi ini dikembangkan dengan tujuan untuk mengurangi beban kerja dari sebuah Evolved Node-B (eNB) atau base station, dimana dua UE atau lebih dapat saling berkomunikasi secara langsung tanpa melalui eNB. Selain itu, teknologi D2D dapat menjangkau perangkat telepon seluler yang berada di luar area cakupan dari suatu jaringan seluler. Dapat dilihat pada Gambar 2, bagaimana ilustrasi komunikasi D2D secara langsung berjalan.

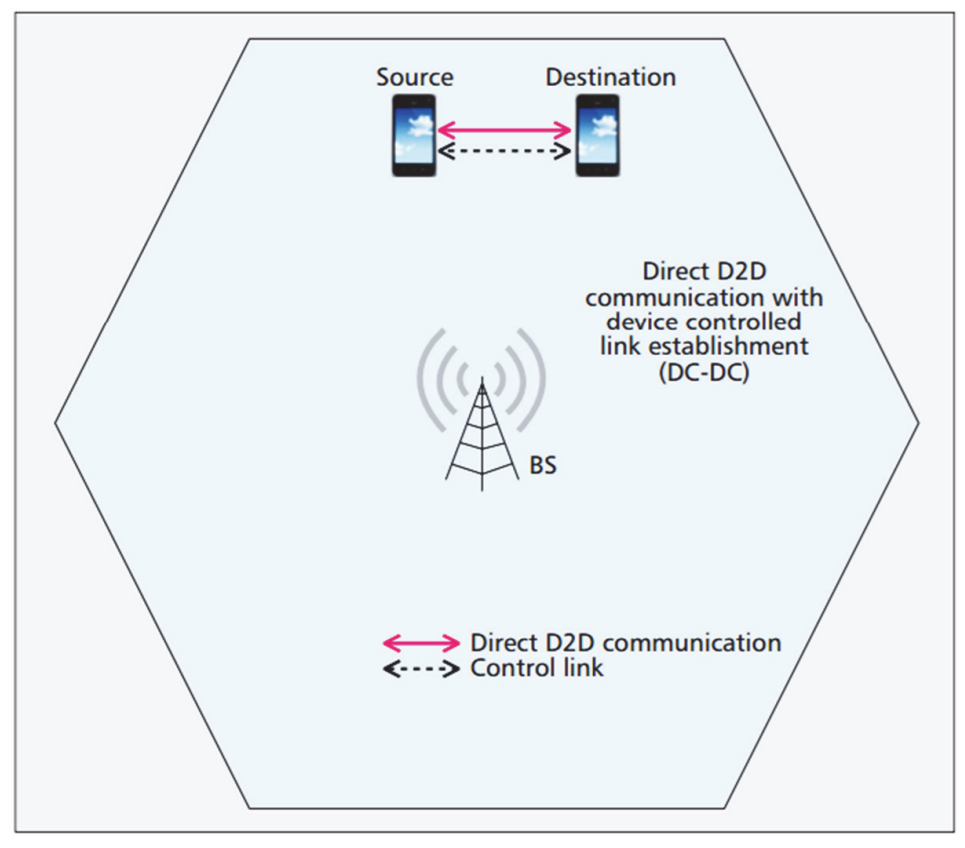

Gambar 2. Ilustrasi komunikasi device to device

Sebelumnya komunikasi D2D dalam jarak pendek sudah dapat dilakukan, salah satunya menggunakan teknologi WI-FI dan bluetooth. WI-FI dan bluetooth menggunakan unlicensed spectrum yang memiliki kelemahan dalam keamanan karena bersifat bebas dan dapat digunakan oleh semua pengguna ketika berada dalam jangkauan komunikasi. Penggunaan unlisenced spectrum juga dapat menyebabkan interferensi antara pengguna satu dengan pengguna lainnya, terutama dalam jumlah pengguna yang banyak. Selain itu, terdapat hambatan pada saat melakukan proses discovery dan pairing antara perangkat satu dengan perangkat yang ingin terhubung. Penggunaan unlicensed spectrum tidak mempunyai kendali yang dapat mengatur koneksi antara pengguna. Sehingga tidak efektif bila digunakan pada saat trafik komunikasi sedang padat, karena dapat mengakibatkan gangguan koneksi dan dapat menimbulkan interferensi yang signifikan. 
Komunikasi D2D yang menggunakan licensed spectrum akan mempunyai tingkat keamanan jaringan yang lebih baik dari unlicensed spectrum. Sehingga D2D dapat melakukan transmisi data secara langsung dengan memanfaatkan resource yang sama seperti digunakan oleh pengguna seluler. Perangkat D2D dapat mengontrol resource tersebut dengan melakukan kerjasama dengan jaringan seluler yang sudah ada. Komunikasi D2D hanya akan tersedia apabila pengguna berada dalam jangkauan jaringan seluler seperti pada jaringan LTE.

Kelebihan dari komunikasi D2D dapat membantu meringankan kinerja dari base station, karena perangkat telepon pengguna yang telah dilengkapi dengan fitur D2D akan dapat melakukan komunikasi secara langsung tanpa melalui base station. Perangkat D2D dapat berperan sebagai relay bagi pengguna telepon seluler konvensional dengan meneruskan sinyal broadcast dari base station menuju pengguna telepon seluler yang berada di luar jangkauan base station. Adapun kekurangan dari komunikasi D2D yakni kehadiran komunikasi D2D dapat menimbulkan interferensi terhadap base station atau terhadap pengguna seluler konvensional yang berada dalam jangkauan perangkat D2D. Akan tetapi, pengaruh interferensi yang ditimbulkan dari komunikasi D2D dapat dikurangi dengan melakukan manajemen interferensi pada komunikasi D2D.

\subsection{Jenis-jenis komunikasi D2D}

Device relaying with operator controlled link establishment (DR-OC), adalah jenis D2D dimana suatu perangkat user menjadi relay yang digunakan sebagai penerus sinyal untuk pengguna lainnya. Dapat dilihat pada Gambar 3, bagaimana ilustrasi dari DR-OC. Perangkat di tepi-tepi sel atau perangkat yang berada pada area jangkauan yang buruk dapat berkomunikasi dengan base station dengan menyampaikan informasinya melalui perangkat lain yang terhubung dengan base station. Ini memungkinkan perangkat untuk mencapai QoS yang lebih tinggi, dan lebih hemat daya. Operator berkomunikasi dengan perangkat yang digunakan sebagai relay untuk pembentukan tautan kontrol parsial atau penuh [7].

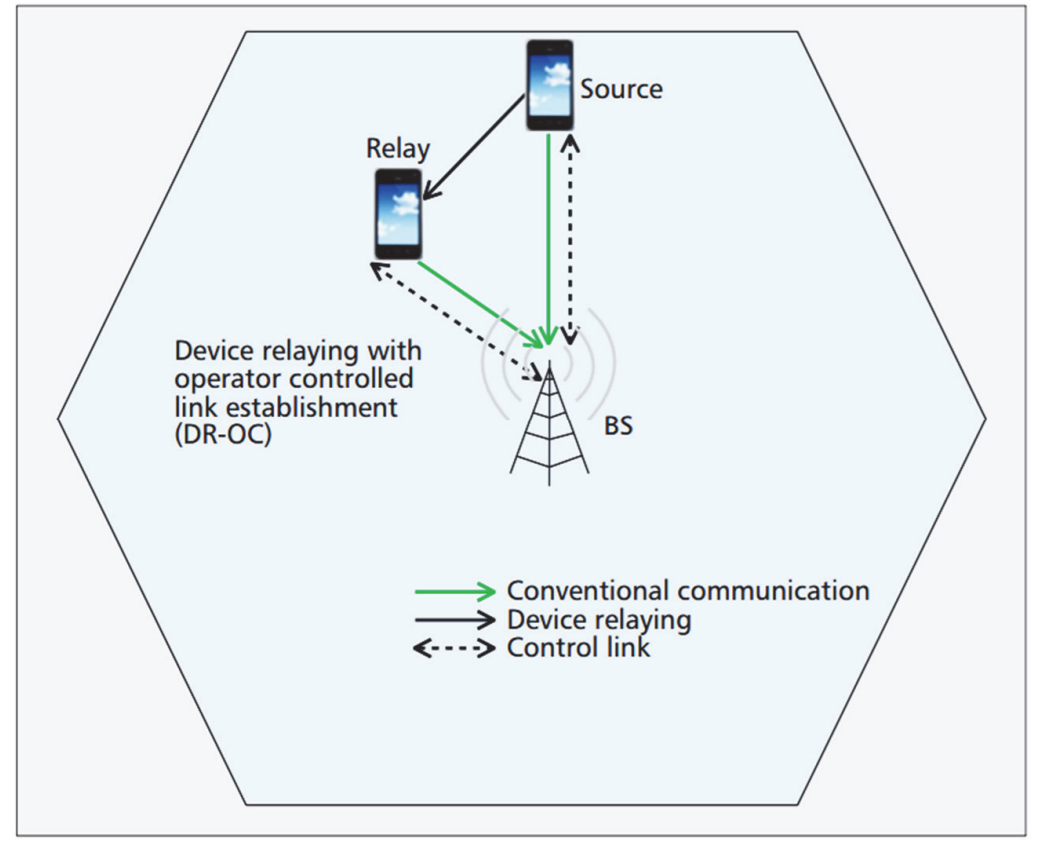

Gambar 3. Ilustrasi D2D jenis DR-OC 
Direct D2D communication with operator controlled link establishment (DC-OC), adalah bentuk D2D dimana dua perangkat user dapat berkomunikasi secara langsung, namun link establishment dibantu oleh base station. Di sini base station berfungsi sebagai pengatur alokasi sumber daya, dan inisiasi komunikasi antar device pengguna. Dapat dilihat pada Gambar 4, bagaimana ilustrasi komunikasi D2D jenis DC-OC.

Dalam DC-OC, perangkat berkomunikasi langsung satu sama lain dengan koneksi yang dikendalikan oleh operator. Secara khusus, operator berurusan dengan otentikasi akses, kontrol, alokasi sumber daya, dan interaksi moneter antar perangkat. Operator memiliki kontrol penuh atas koneksi D2D, termasuk fungsi bidang kontrol (seperti pengaturan dan pemeliharaan koneksi), dan fungsi bidang data (alokasi sumber daya). Koneksi D2D pada tier perangkat berbagi pita berlisensi seluler dengan koneksi seluler reguler di tier macrocell. Jaringan dapat secara dinamis menetapkan sumber daya untuk setiap koneksi D2D dengan cara yang sama seperti koneksi seluler biasa atau secara semi-statis menetapkan kumpulan sumber daya khusus untuk semua koneksi D2D.

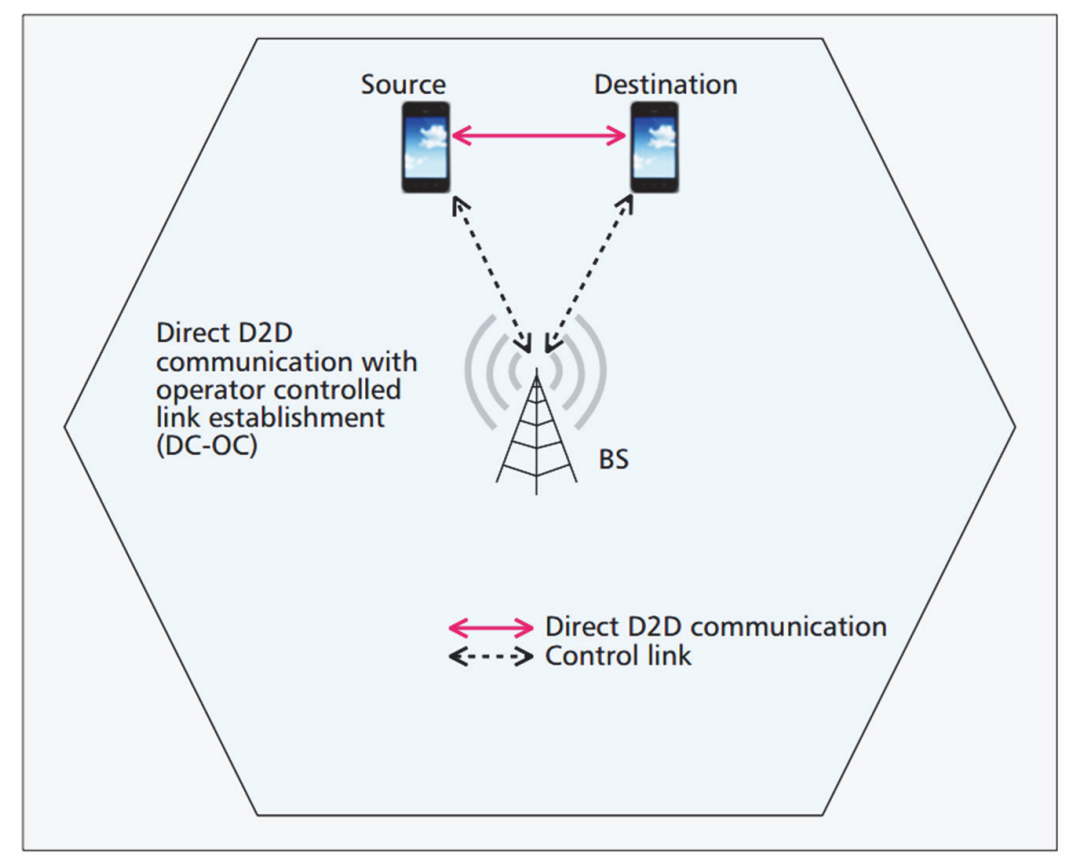

Gambar 4. Ilustrasi D2D jenis DC-OC

Salah satu jenis lainnya adalah device relaying with device controlled link establishment $(D R-D C)$, pada jenis ini operator tidak terlibat dalam proses pembentukan tautan. Oleh karena itu, perangkat sumber dan tujuan bertanggung jawab untuk mengoordinasikan komunikasi menggunakan relay antara satu sama lain. Dapat dilihat pada Gambar 5, bagaimana ilustrasi DR-DC. Jenis lain dari D2D adalah direct D2D communication with device controlled link establishment $(D C-D C)$, tipe ini adalah dimana user berhubungan secara langsung tanpa terhubung dengan base station, seperti yang dapat dilihat pada Gambar 2. Dalam DR-DC dan DC-DC, tidak ada base station atau server untuk mengontrol komunikasi antar perangkat. 


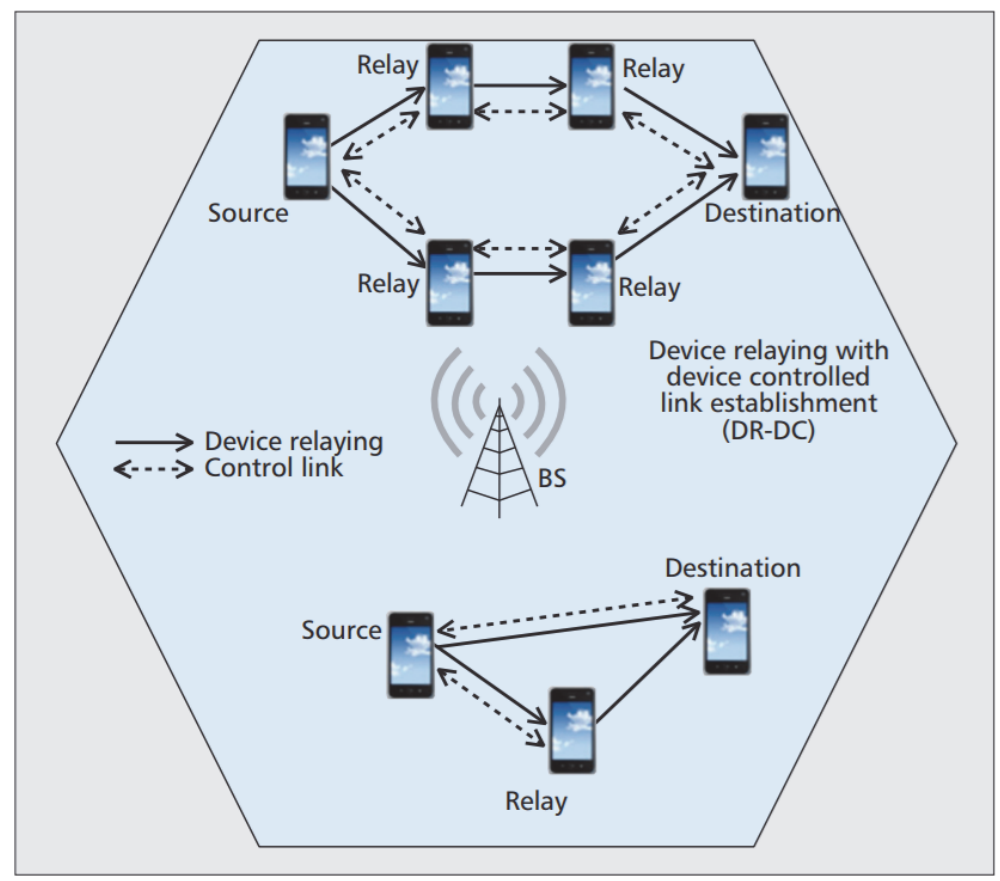

Gambar 5. Ilustrasi D2D jenis DR-DC

Seperti yang ditunjukkan pada Gambar 2 dan 5, beberapa perangkat berkomunikasi satu sama lain menggunakan komunikasi kooperatif dan non-kooperatif, dan juga satu atau beberapa perangkat dapat menjadi peran relay untuk perangkat lain. Jenis komunikasi ini lebih kompleks daripada yang sebelumnya, karena tidak ada pengawasan terpusat untuk mengatur jalannya komunikasi. Pengaturan koneksi, manajemen interferensi, dan alokasi sumber daya karenanya harus ditangani menggunakan metode terdistribusi. Sebelum fase transmisi data, dua perangkat harus saling menemukan dan relay yang berdekatan. Perangkat dapat secara berkala membroadcast informasi identitas sehingga perangkat lain dapat mengetahui keberadaannya dan memutuskan apakah mereka dapat memulai komunikasi D2D langsung atau tidak [7].

\subsection{Load Balancing untuk 5G}

Load balancing adalah pendekatan yang efektif untuk mengatasi masalah fluktuasi spasial-temporal dari lalu lintas data seluler untuk jaringan seluler, dapat dilihat pada Gambar 6, bagaimana trafik yang ada dapat terbagi dengan adanya D2D. Pada penggunaan 5G mmWave, sel yang dihasilkan akan sangat kecil dan pada titik tertentu pada sel kecil itu akan terjadi trafik yang sangat besar karena berkumpulnya user pada satu titik tertentu. Hal ini dapat menyebabkan sisttem seluler terlalu penuh dan akan terjadi penurunan kecepatan dan kualitas sinyal yang diterima oleh user. Dengan menggunakan D2D, masalah ini dapat diatasi, namun membutuhkan skema yang efektif untuk menjalankan load balancing, alokasi sumber daya harus tepat dan juga permasalahan routing yang sangat kompleks. Skema yang sekarang diterapkan berfokus pada peminjaman saluran dari sel tetangga, hal ini tidak dapat langsung diterapkan ke jaringan nirkabel 5G di masa depan, karena sel tetangga akan menggunakan kembali pita spektrum yang sama dalam sistem $5 \mathrm{G}$. 


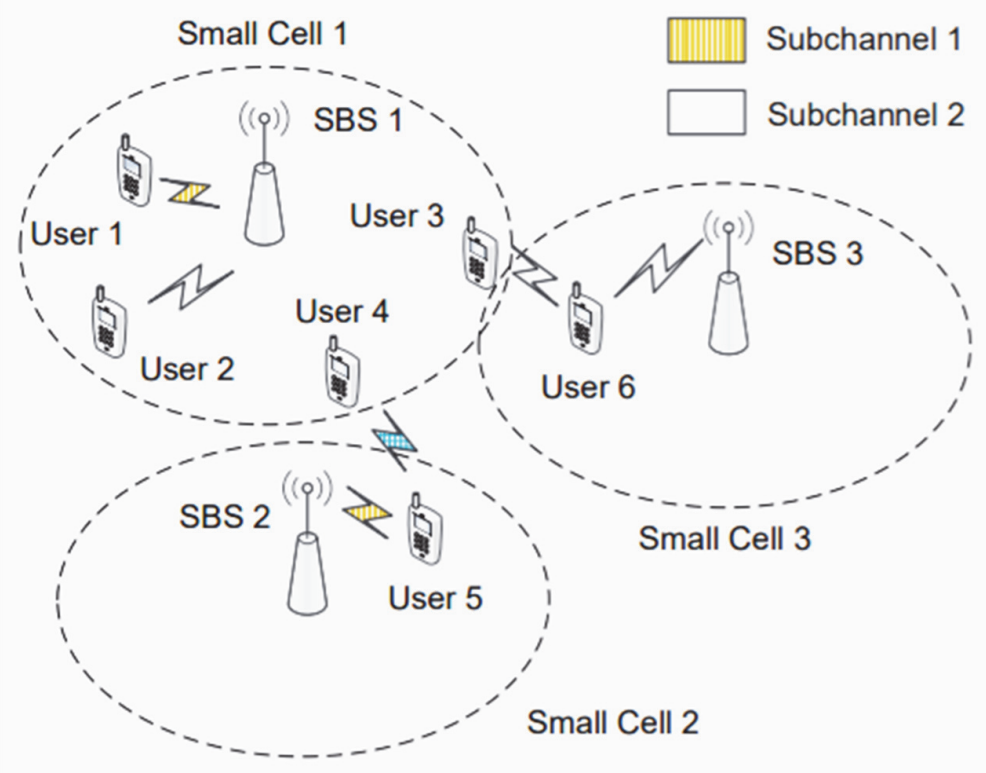

Gambar 6. Model sistem load balancing [6].

Dengan mempertimbangkan jaringan multi-frekuensi pembagian ganda (OFDMA) frekuensi ultra orthogonal, dimana komunikasi Device to-Device (D2D) akan memfasilitasi keseimbangan beban tanpa spektrum tambahan. Secara khusus, lalu lintas data dapat secara efektif diturunkan dari sel kecil padat ke sel kecil lainnya yang kurang dimanfaatkan oleh komunikasi D2D. Masalahnya secara alami dirumuskan sebagai alokasi sumber daya bersama dan masalah rute D2D yang memaksimalkan jumlah sistem. Untuk memecahkan masalah secara efisien, masalah dipisahkan menjadi dua, alokasi sumber daya dan subproblem routing pada D2D. Kedua masalah ini dapat diselesaikan secara iteratif sebagai masalah optimisasi monotonik dan masalah pemrograman geometri komplementer. Dibutuhkan suatu algoritma yang dapat mengatur trafik dan menyelesaikan masalah beban trafik yang berlebihan dalamsatu sel. Simulasi dilakukan untuk mewujudkan load balancing paling efektif untuk dapat diimplementasikan pada jaringan 5G untuk mengatasi permasalahan padatnya 1 sel dengan cakupan yang kecil. Hasil simulasi menunjukkan bahwa tingkat jumlah data dalam sel kecil tetangga meningkat rata-rata $20 \%$ dengan menurunkan lalu lintas data dalam sel kecil padat ke stasiun pangkalan sel kecil terdekat (SBS) [8].

\section{Optimasi Efisiensi Energi Pada D2D}

Salah satu permasalahan utama dalam implementasi D2D dalam sistem seluler $5 \mathrm{G}$ adalah dibutuhkannya suatu skema untuk dapat mengoptimasi efisiensi spektrum dan energi yang digunakan. Permasalahan energi juga menjadi krusial, karena kebanyakan perangkat pengguna memiliki daya yang sangat terbatas. Sistem D2D menjadi hal yang percuma jika sistem yang dipakai akan menguras habis daya yang dimiliki oleh perangkat pengguna.

Salah satu cara yang telah diteliti sebagai solusi untuk optimisasi efisiensi energi adalah dengan membuat sistem yang social-aware untuk komunikasi D2D di jaringan 5G dengan menerapkan algoritma adaptive genetic dengan cermat dan mempertimbangkan hubungan sosial dan gangguan fisik antara semua pengguna. Gangguan timbal balik dalam lingkungan komunikasi D2D, kendala daya transmisi dan persyaratan efisiensi spektrum, terutama dampak hubungan sosial, harus diperhatikan untuk mengetahui pemilihan mode saluran optimal dan kekuatan transmisi yang dialokasikan untuk semua pengguna dalam jaringan. Sistem ini, 
berjalan sesuai dengan keadaan pengguna dalam sel, dengan memanfaatkan interaksi sosial antar pengguna untuk menciptakan efisiensi dalam penggunaan energi pada D2D.

Hasil numerik menunjukkan bahwa optimalisasi efisiensi energi dengan sistem socially-aware dapat sangat meningkatkan efisiensi energi dan throughput sistem untuk komunikasi D2D dan juga menjaga efisiensi spektrum dan masalah efisiensi daya transmisi untuk menghasilkan QoS yang tinggi [9]. Pada penelitian yang telah dilakukan, efisiensi energi diukur dengan bit rate yang didapatkan per satuan watt (kbps/watt). Dari hasil simulasi yang dilakukan, dengan menggunakan sistem socially-aware didapatkan efisiensi terbesar senilai $1000 \mathrm{kbps} /$ watt, sedangkan pada sistem yang tidak socially-aware memiliki efisiensi terbesar senilai $500 \mathrm{kbps} /$ watt. Hal ini menunjukan peningkatan dua kali lipat pada efisiensi energi [9]. Dapat dilihat pada Gambar 7, bagaimana ilustrasi dari sistem optimalisasi efisiensi energi menggunakan sistem yang socially aware.

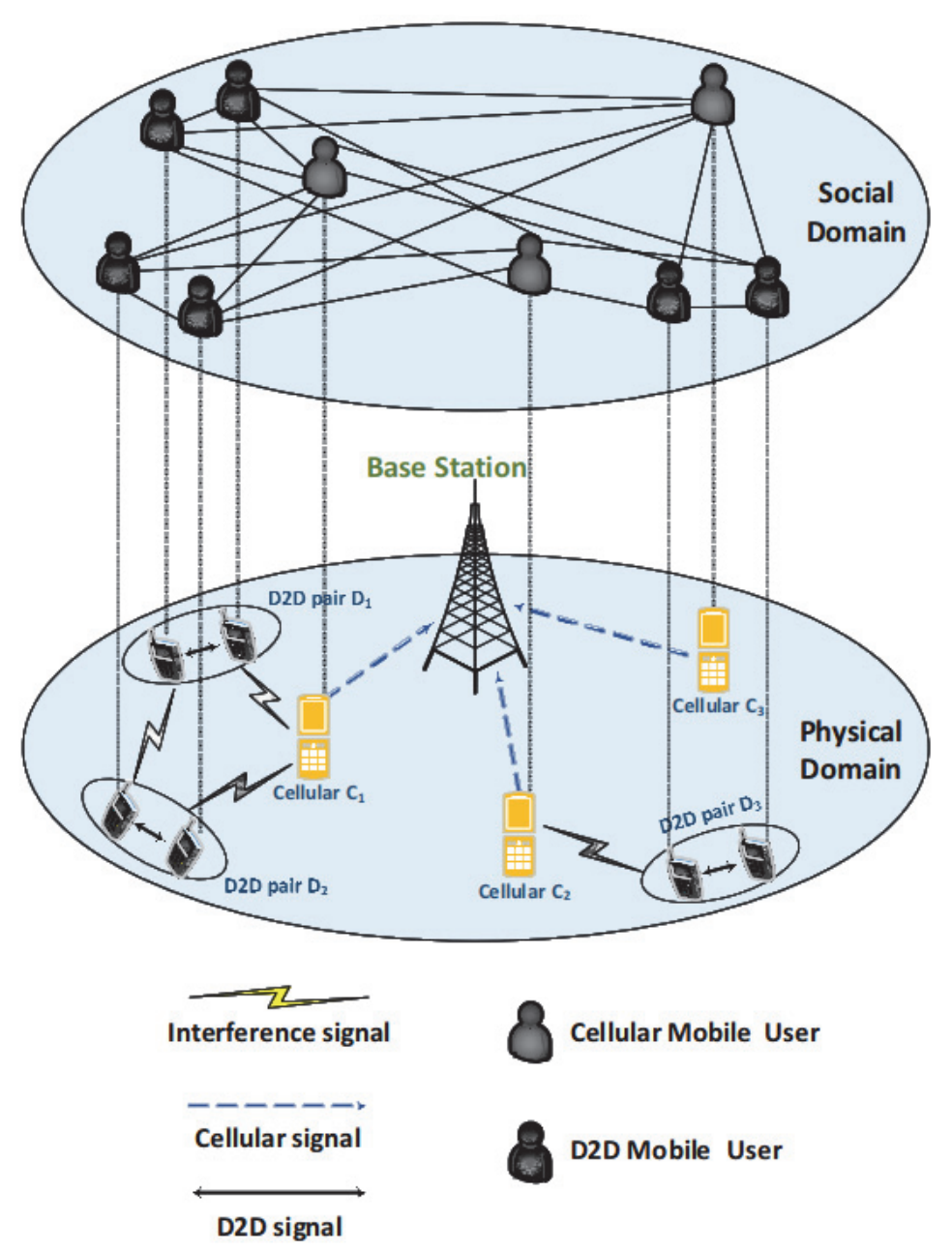

Gambar 7. Socially-aware energy efficiency system [7]

\section{Kesimpulan}

Komunikasi device-to-device (D2D) adalah jenis komunikasi yang memungkinkan perangkat user dapat terhubung secara langsung, dan meminimalisir peran dari base station. Dengan menggunakan D2D, cakupan sel akan menjadi lebih luas, dengan memanfaatkan pengguna yang terhubung dengan base station sebagai relay yang meneruskan sinyal ke pengguna-pengguna lainnya. D2D juga digunakan untuk load balancing. Dimana D2D 
digunakan sebagai penyeimbang beban trafik yang terjadi antar sel. Dengan menggunakan D2D diperlukan alokasi sumber daya dan routing yang tepat, agar D2D dapat membantu load balancing saat diemplementasikan pada $5 \mathrm{G}$.

Optimalisasi energi pada sistem D2D dapat dilakukan dengan menggunakan sistem socially aware. Untuk mendapatkan daya yang efisien berdasarkan keadaan pengguna dan interaksi sosial antar pengguna.

Untuk ke depannya sangat dibutuhkan banyak penelitian untuk dapat menemukan use case ideal dari D2D yang dapat secara nyata diimplementasikan pada jaringan seluler secara komersil, dengan memperhitungkan kenyamanan pengguna, operator, dan badan regulator.

\section{Daftar Pustaka}

[1] European Telecommunications Standards Institute (ETSI), 4th Generation (LTE), European Telecommunications Standards Institute, online: https://www.etsi.org/technologies/mobile/4g. Diakses 26 Januari 2020.

[2] European Telecommunications Standards Institute, $5 G$, European Telecommunications Standards Institute, online: https://www.etsi.org/technologies/mobile/5g. Diakses 26 Januari 2020.

[3] Al-Falahy, N., \& Alani, O. Y. (2019). Millimetre wave frequency band as a candidate spectrum for 5G network architecture: a survey. Physical Communication, 32, 120-144.

[4] Molu, M. M., Xiao, P., Khalily, M., Cumanan, K., Zhang, L., \& Tafazolli, R. (2017). Low-complexity and robust hybrid beamforming design for multi-antenna communication systems. IEEE Transactions on Wireless Communications, 17(3), 14451459.

[5] Turkmen, A., Mollel, M. S., Ozturk, M., Yao, S., Zhang, L., Ghannam, R., \& Imran, M. A. (2019, August). Coverage Analysis for Indoor-Outdoor Coexistence for MillimetreWave Communication. In 2019 UK/China Emerging Technologies (UCET) (pp. 1-4). IEEE.

[6] GC, D., Ladas, A., \& Politis, C. (2019). Robust Device-to-Device 5G cellular communication in the post-disaster scenario. In 2019 16th IEEE Annual Consumer Communications \& Networking Conference (CCNC).

[7] Tehrani, M. N., Uysal, M., \& Yanikomeroglu, H. (2014). Device-to-device communication in $5 \mathrm{G}$ cellular networks: challenges, solutions, and future directions. IEEE Communications Magazine, 52(5), 86-92.

[8] Zhang, H., Song, L., \& Zhang, Y. J. (2018). Load balancing for 5G ultra-dense networks using device-to-device communications. IEEE Transactions on Wireless Communications, 17(6), 4039-4050.

[9] Huynh, D. T., Wang, X., Duong, T. Q., Vo, N. S., \& Chen, M. (2018). Social-aware energy efficiency optimization for device-to-device communications in $5 \mathrm{G}$ networks. Computer Communications, 120, 102-111. 